\title{
The SSHPA Project
}

Subjects: Information Science \& Library Science | Others | Communication

Contributors: Ho Manh Toan, Minh-Hoang Nguyen

(i)

Submitted by: Ho Manh Toan

\section{Definition}

Social Sciences \& Humanities Peer Awards (SSHPA) is an ecosystem of a scientific database and a science communication website. The project was funded by Vietnam National Foundation for Science and Technology Development (NAFOSTED) under the National Research Grant No. 502.01-2018.19. The SSHPA database was validated by Nature's Scientific Data.

\section{Introduction}

The Social Sciences Humanities Peer Award (SSHPA) is the first effort to build a comprehensive database of Vietnamese social sciences and humanities researchers. The project was initiated by Dr. Vuong Quan Hoang, and funded by Vietnam National Foundation for Science and Technology Development (NAFOSTED) under the National Research Grant No. 502.01-2018.19 from 2018 until 2021. The SSHPA project consists of the first Vietnamese national database on social sciences and humanities and the first Vietnamese science communication website.

The SSHPA database is accessible from URL: https://sshpa.com/.

The SSHPA SciComm system is accessible from URL: https://sc.sshpa.com/.

\section{The SSHPA database}

The SSHPA database is an open database on the scientific output of Vietnamese researchers in social sciences and humanities ${ }^{[\underline{1}]}$. An in-depth exploration of the database was published in Nature's Scientific

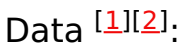

"This study presents a description of an open database on scientific output of Vietnamese researchers in social sciences and humanities, one that corrects for the shortcomings in current research publication databases such as data duplication, slow update, and a substantial cost of doing science. Here, using scientists' self-reports, open online sources and cross-checking with Scopus database, we introduce a manual system and its semi-automated version of the database on the profiles of 657 Vietnamese researchers in social sciences and humanities who have published in Scopus-indexed journals from 2008 to 2018. The final system also records 973 foreign co-authors, 1,289 papers, and 789 affiliations. The data collection method, highly applicable for other sources, could be replicated in other developing countries while its content be used in cross-section, multivariate, and network data analyses. The open database is expected to help Vietnam revamp its research capacity and meet the public demand for greater transparency in science management."

The database has been a foundation for many scientific publications from 2017 until now:

1. Gender, age, research experience, leading role and academic productivity of Vietnamese researchers in the social sciences and humanities: exploring a 2008-2017 Scopus dataset [3] $]$.

2. Exploring Vietnamese co-authorship patterns in social sciences with basic network measures of 20082017 Scopus data [].

3. Nemo solus satis sapit: trends of research collaborations in the Vietnamese social sciences, observing 2008-2017 Scopus data [ㅌ].

4. On the sustainability of co-authoring behaviors in Vietnamese social sciences: A preliminary analysis of network data []. 
5. The (in)significance of socio-demographic factors as possible determinants of Vietnamese social scientists' contribution-adjusted productivity: preliminary results from 2008-2017 Scopus data [].

6. An open database of productivity in Vietnam's social sciences and humanities for public use [1].

7. The harsh world of publishing in emerging regions and implications for editors and publishers: The case of Vietnam [요.

8. Breaking barriers in publishing demands a proactive attitude [9].

9. The Vietnamese Social Sciences at a Fork in the Road (Book; ISBN:978-3-11-068608-1) [밍.

10. Effects of work environment and collaboration on research productivity in Vietnamese social sciences: evidence from 2008 to 2017 Scopus data [11].

11. Making social sciences more scientific: Literature review by structured data [12].

12. Multi-faceted insights of entrepreneurship facing a fast-growing economy: A literature review [13].

13. What have Vietnamese scholars learned from researching entrepreneurship?: A systematic review [14].

14. The Internal Capability of Vietnam Social Sciences and Humanities: A Perspective from the 2008-2019 Dataset $[\underline{15}]$.

15. Adopting open access in the social sciences and humanities: Evidence from a developing nation [트.

16. Mirror, mirror on the wall: Is economics the fairest of them all? An investigation into the social sciences and humanities in Vietnam [1]7].

17. Top economics universities and research institutions in Vietnam: Evidence from the SSHPA dataset $[\underline{18}]$.

18. Adopting open access in an emerging country: Is gender inequality a barrier in Humanities and Social Sciences? ${ }^{[19]}$.

19. A systematic and critical review on the research landscape of finance in Vietnam from 2008 to 2020 [미].

\section{The SSHPA SciComm system}

The SSHPA SciComm system shares techniques, experiences in conducting research, publishing papers internationally, writing a research paper, and meeting the demand of peer reviewers, and updating new findings in the social sciences and humanities. The goal is to elevate the status of Vietnamese SS\&H worldwide and reduce the cost of doing science $[\underline{21]}$ in the Vietnamese social sciences community.

The SSHPA SciComm system has contributed important insights about science to the Vietnamese public, notably:

1. Journal Impact Factor 2020: Một số quan sát từ dữ liệu SSHPA [22].

2. Hệ thống công bố khoa học: Chỉ mục tạp chí và hệ số tác động JIF, CiteScore [23] .

3. KHXH\&NV: Hơn một thập kỷ tăng số lượng và chất lượng công bố quốc tế [24].

\section{References}

1. Vuong QH, et al. (2018). An open database of productivity in Vietnam's social sciences and humanities for public use. Scientific Data, 5, 180188.

2. Ngọc Huyền. (26 September, 2018). Nghiên cứu do NAFOSTED tài trợ vừa được công bố trên tạp chí Scientific Data. Khoa học và Phát triển. URL: https://khoahocphattrien.vn/thoi-su-trong-nuoc/nghien-cuu-do-nafosted-tai-tro-vua-duoccong-bo-tren-tap-chi-scientific-data/20180926112813918p882c918.htm

3. Vuong QH, et al. (2017). Gender, age, research experience, leading role and academic productivity of Vietnamese researchers in the social sciences and humanities: exploring a 2008-2017 Scopus dataset. European Science Editing 43(3): 51-55.

4. Ho TM, et al. (2017). Exploring Vietnamese co-authorship patterns in social sciences with basic network measures of 2008-2017 Scopus data. F1000Research, 6, 1559.

5. Vuong QH, et al. (2017) Nemo solus satis sapit: trends of research collaborations in the Vietnamese social sciences, observing 2008-2017 Scopus data. Publications, 5(4), 24

6. Ho TM, et al. (2017). On the sustainability of co-authoring behaviors in Vietnamese social sciences: A preliminary analysis of network data. Sustainability, 9(11), 2142.

7. Vuong $T$, et al. (2018). The (in)significance of socio-demographic factors as possible determinants of Vietnamese 
social scientists' contribution-adjusted productivity: preliminary results from 2008-2017 Scopus data. Societies, 8(1), 3.

8. Vuong QH. (2019). The harsh world of publishing in emerging regions and implications for editors and publishers: The case of Vietnam. Learned Publishing, 32(4), 314-324

9. Vuong QH. (2019). Breaking barriers in publishing demands a proactive attitude. Nature Human Behaviour, 3(10), 1034.

10. Vuong QH, Tran T. (Ed.) (2019). The Vietnamese Social Sciences at a Fork in the Road. Warsaw, Poland: De Gruyter (Edition: Sciendo).

11. Vuong QH, et al. (2019). Effects of work environment and collaboration on research productivity in Vietnamese social sciences: evidence from 2008 to 2017 Scopus data. Studies in Higher Education, 44(12), 2132-2147

12. Vuong QH, et al. (2020). Making social sciences more scientific: Literature review by structured data. MethodsX, 7, 100818

13. Vuong QH et al. (2020). Multi-faceted insights of entrepreneurship facing a fast-growing economy: A literature review. Open Economics, 3(1), 25-41.

14. Vuong QH, et al. (2020). What have Vietnamese scholars learned from researching entrepreneurship?: A systematic review. Heliyon, 6, e03808

15. Ho MT, et al. (2020). The Internal Capability of Vietnam Social Sciences and Humanities: A Perspective from the 20082019 Dataset. Publications, 8(2), 32

16. Vuong TT, et al. (2020). Adopting open access in the social sciences and humanities: Evidence from a developing nation. Heliyon, 6(7), e04522.

17. Vuong QH, et al. (2021). Mirror, mirror on the wall: Is economics the fairest of them all? An investigation into the social sciences and humanities in Vietnam. Research Evaluation, 30: in-press.

18. Vuong QH, et al. (2021). Top economics universities and research institutions in Vietnam: Evidence from the SSHPA dataset. Heliyon, 7(2), e06273.

19. Vuong QH, et al. (2021). Adopting open access in an emerging country: Is gender inequality a barrier in Humanities and Social Sciences?. Learned Publishing, 34.

20. Ho MT, et al. (2021). A systematic and critical review on the research landscape of finance in Vietnam from 2008 to 2020. Journal of Risk Financial Management, 14(5), 219.

21. Vuong QH. (2019). The (ir)rational consideration of the cost of science in transition economies. Nature Human Behaviour, 2, 5. https://doi.org/10.1038/s41562-017-0281-4

22. Hồ Mạnh Toàn, Nguyễn Thanh Thanh Huyền, Phạm Hùng Hiệp. (2021, July 15). Journal Impact Factor 2020: Một số quan sát từ dữ liệu SSHPA. Kinh tế và Dự báo. URL: https://kinhtevadubao.vn/journal-impact-factor-2020-mot-so-quansat-tu-du-lieu-sshpa-18340.html

23. Hồ Mạnh Toàn. (2021, June 22). Hệ thống công bố khoa học: Chỉ mục tạp chí và hệ số tác động JIF, CiteScore. Kinh tế và Dự báo. URL: https://kinhtevadubao.vn/he-thong-cong-bo-khoa-hoc-chi-muc-tap-chi-va-he-so-tac-dong-jif-citescore18019.html

24. Nguyễn Thanh Thanh Huyền, Nguyễn Thanh Dung, Nguyễn Thanh Nhàn, Lương Anh Phương, Nguyễn Thị Linh, Lê Thị Kim Ngân, Hồ Mạnh Toàn. (16 Jan, 2020). KHXH\&NV: Hơn một thập kỷ tăng số lượng và chất lượng công bố quốc tế. Khoa học và Phát triển. URL: http://khoahocphattrien.vn/chinh-sach/khxhnv-hon-mot-thap-ky-tang-so-luong-va-chatluong-cong-bo-quoc-te/20200113023839782p1c785.htm

\section{Keywords}

SSHPA;Vietnam;Social Sciences and Humanities;Science Communication;SciComm 